In the present instance, there is added its bearing on the site of Skara Brae, the similar village discovered and excavated some ten years ago, of which the significance for our knowledge of stone age culture and more of life was such that Prof. V. Gordon Childe at the time described it as a veritable Knossos of the north. The new site defines more nearly the dating of the culture, left somewhat indeterminate, at Skara Brae. The discovery of a portion of a beaker, in association with objects of the Skara Brae type, fixes the period of occupation at somewhere about the transition from stone to bronze in Great Britain, that is at about 1500 B.c. Further the Rinyo village, being apparently complete, should supply details which at Skara Brae had been swept away by the encroachments of the sea on the sand dunes. The Rinyo settlement has been excavated by Mr. Walter W. Grant, with whom has been associated Prof. Gordon Childe. Below the floor in which the beaker fragment was discovered, traces of earlier occupation have been found. These are in the form of commodious stone houses, provided with recesses for beds, built dressers and even a system of drainage. In addition to open hearths, some of the houses have clay ovens, a novel feature. It is anticipated that eventually excavation will give a complete picture of a whole stone age settlement, unique in Britain, and indeed in western Europe, and at the same time throw a new light on the social organization and economy of a neolithic community.

\section{Rhodesian National Museum}

IN reference to the announcement of the proposed National Museum for Southern Rhodesia in the neighbourhood of the Zimbabwe ruins (see NATURE, July 9, p. 65), Mr. F. M. Collins writes to suggest the possibility of a confusion between the Victoria Falls and Fort Victoria, the township one hundred and eighty miles east of Buluwayo, near which the ruins are situated, while their distance from the Falls is by air approximately four hundred miles. 'Proximity', however, the term in the comment in these columns to which $\mathrm{Mr}$. Collins takes exception, is, as he admits, relative, and as the general sense indicated was used in comparison with, for example, the distance from Cape Town, which would affect students and tourists, rather than in relation to absolute mileage.

\section{Science and the Way to Peace}

AN "Appeal to the Scientists of the World" has reached us from India. The author, Dr. Bhagavan Das of Benares, a member of the Legislative Assembly of India, refers to the imminent peril of another world war, far surpassing the last in horror and destructiveness, and the frightful strain meanwhile imposed on mankind by preparation for defence. $\mathrm{He}$ seeks to show that a heavy responsibility for this state of affairs rests on the learned world as a whole, partly because modern warfare owes its peculiarly devastating character to scientific research and the collaboration of men of science with the organizers of war and partly because the ideas that motivate wars are products of the speculations of philosophers and the vulgarization and misapplication of theories invented by men of science, notably that of the ascent of man through the struggle for existence and survival of the fittest. He quotes from the records of ancient Aryan wisdom: "Science (Vidya) came to the man of wisdom, the man of knowledge and purity, and said to him : guard me as a sacred trust ; give me not to the wicked and sinful, but only to the pure of heart and large of mind; so only will I be strong to nourish mankind; otherwise I will only destroy thee and thy pupils and thy people." So in our own day Alexis Carrel in "Man the Unknown" writes: "The environment which science and technology have succeeded in developing for man does not suit him because it has been constructed at random without regard for his true self." Therefore, the appeal says, it is "up to" the learned world to get together and do something about it. Peradventure where politicians have failed men of science may find a way of approach to disarmament, military and economic.

\section{The Ontario Research Foundation}

THE report of the Ontario Research Foundation for 1937 (Sessional Paper, No. 52. Pp. 35. Toronto : King's Printer) refers to an increase in the amount of research work carried out in contact and in co-operation with industrial companies, the revenue received for services rendered to industry itself having increased by thirty per cent. The Textiles Department has during the year developed a launderometer for determining the fastness of dyed goods to washing, a fadeometer for determining the fastness of coloured fabrics to light, a crock-meter for determining fastness of dyes to rubbing, and an autographic tensile strength and elongation tester for determining the strength, extensibility and yarn slippage of materials. The Engineering and Metallurgy Department continued its investigation on summer comfort standards for the Toronto district and also its study of the resistance to abrasion of iron and steel balls under the conditions existing in the grinding mills of mines. In the Department of Chemistry, the development of a laboratory for the study of problems relating to paper, printing and adhesives has been completed. Work on the transfer of pigments from aqueous pastes to an oily medium by methods which are commercially feasible lıas reached its final stages and in addition to the mechanical problem an emulsifying agent is required which is not detrimental to the final product. The equipment and organization of a laboratory for the study of plastics has been commenced, and a new laboratory has also been inaugurated to study problems associated with the manufacture of waxed paper and similar products. The Department of Biochemistry has continued its investigations on a combined system of tannage for sole and belting leather and on problems connected with the Matzka process for the preparation of fruit juices which are stable for prolonged periods and retain their original flavour and content of vitamins. Investigations carried out by the Department of Agriculture have 
related to mineral deficiencies of land types and the relation between soil, climate and cultivation of the principal crops in Ontario, while the Department of Pathology and Bacteriology has continued its studies of bovine mastitis and the parasites of sheep.

\section{The Carnegie Institution of Washington}

The Yearbook of the Carnegie Institution of Washington, July 1, 1936-June 30, 1937, contains the reports of the Executive Committee and of the president for the year ended October 31, 1937, together with reports on investigations received up to December 10 and a bibliography of publications issued during the year by the Institution or of the Institution's staff through all channels (Washington : Carnegie Institution of Washington). The president's report again refers to the relations between science and social problems and to the importance in society not merely to appreciate the difficulties in interpretation of the influence of science but also to be aware of the interdependence among social elements in the same way that we are aware of the interrelations among elements involved in the unity of Nature. The Geophysical Laboratory has continued researches to determine with all possible precision the underlying causes of geological and geophysical phenomena. A major advance in the terrestrial-magnetic research is reported by Dr. J. A. Fleming, in the proof of the association of a special type of magnetic disturbance and sharp fade-outs of high-frequency radio-wave reflections with bright eruptions in the solar chromosphere. With this advance, the Mount Wilson Observatory was also associated, and the Observatory also expanded greatly the scope of solar investigations with the rapid increase in solar activity. The Division of Plant Biology has continued to study the ecology of the Great Plains and its bearing on the agricultural and human population of that area. The Division of Animal Biology has made several observations fundamental to the cancer problem, and the value of diverse approaches by different groups of workers is well illustrated in this work as in reports from the Divisions of Embryology, the Nutrition Laboratory and the Department of Genetics in the field of endocrinology.

\section{Technical Colleges of South Africa}

The Carnegie Corporation of New York has lately issued a critical study by Dr. F. H. Spencer of the technical colleges of South Africa. Dr. Spencer has had experience of technical education in Great Britain, and this has enabled him to make some interesting comparisons. The technical colleges provide $(a)$ full-time pre-apprenticeship courses for pupils aged 14-17 or 18, (b) part-time courses for apprentices and others already at work. The place accorded in the full-time courses to general cultural work is, by British standards, inadequate, geography being dropped after the first year, while history, even from the economic point of view, does not enter the picture. The part-time courses, which are everywhere the largest part of the technical college work, are dominated by the Apprenticeship Law. This enactment has conferred on South Africa some of the benefits which in Great Britain should have resulted from the clauses of the Fisher Act providing for daytime continuation education from 14 to 18. In South Africa, despite a certain amount of recalcitrance, the Apprentice Law is an undoubted success. Apprentices attend ordinarily about eight hours a week of which half is taken from day-time working hours. The great merit of the system is that the compulsory attendance is almost universally followed up to an advanced stage by a not unsatisfactory proportion of the apprentices. This advanced stage, at least for the constructional trades, is comparable with university work, and those who pass through it to the national certificate stage "will furnish the 'non-commissioned' staff of industry who are as essential to success as the management"

\section{The Belgian Grid}

IN Electrical Industries of July, W. Fennell gives a review of the salient engineering features of the Belgian Grid, which began by the co-operation in 1919 of isolated supply companies. These companies, mostly in the southern and eastern provinces (Liège, etc.), happened to be in close contact with heavy industries. They realized the existence of by-product power 'going to waste' at the large industrial works and saw that in some cases it would be economical to use this power rather than to build large power stations or extend small ones. A power production combine was formed to further the interests of manufacturers who had blast furnace and coke oven gas and process steam available greatly in excess of their own power requirements. In addition, they had engines used as stand-by plant, much of which would not be necessary if the various works' plants were interconnected. The electricity supply com. panies also had means of utilizing the waste power. This combine has spread so that it includes practically the whole country under a grouping system. All the undertakings and associated works are linked up into two networks, north and south, which are them. selves interconnected. The production of power, while remaining under local control, is directed by a national co-ordinating company. The tariff applied to plant owners is based on the principle that the amounts they pay or receive are equal to the re. duction or increase of expenditure entailed in their installations by running in parallel, compared with independent working The success that Belgium has attained as a competitor in the steel and chemical industries indicates that this co-operative experiment, now twenty years old, has been a substantial con. tributory cause.

\section{Conservation of Natural Resources}

UNDER this title, the American Association for the Advancement of Science has issued a selected list of literature dealing with various aspects of the subject. Almost too late, rather than too soon, the United States is becoming conscious of the significance of the vast subject of conservation. The very word is itself 